\title{
O controle judicial da execução penal no Brasil: ambiguidades e contradições de uma relação perversa
}

\author{
The judicial control of criminal execution in Brazil: \\ ambiguities and contradictions of a perverse relationship
}

\section{Patrick Cacicedo ${ }^{1}$}

Universidade de São Paulo - São Paulo/SP

patrickcacicedo@gmail.com

lattes.cnpq.br/6868425451997606

orcid.org/0000-0002-5623-8224

Resumo: O presente estudo objetiva analisar criticamente o controle judicial da execução penal no Brasil. A partir de três aspectos distintos da execução penal, busca-se expor as ambiguidades e contradições da jurisdicionalização da execução das penas no Brasil, cujo debate doutrinário não tem ido além da natureza jurídica deste campo do direito. Para além do debate acerca da necessidade de um controle judicial da execução penal no Brasil, pretende-se apontar para a complexidade da questão a partir de problemas concretos pouco abordados pelos autores da área. Assim, a análise do controle judicial do sistema progressivo, da questão disciplinar, bem como dos direitos relacionados às condições materiais de aprisionamento permite desvelar graves problemas que a temática engendra, especialmente no que se refere às formas de gestão e controle das pessoas presas, de modo a contribuir com o debate para um campo do direito que carece de aprofundamento científico.

Palavras-Chave: controle judicial; execução penal; sistema progressivo; poder disciplinar; condições de aprisionamento.

ABSTRACT: This study aims to analyze critically the judicial control of criminal execution in Brazil. Based on three distinct aspects of criminal execution, it seeks to expose the ambiguities and contradictions of the jurisdictionalisation of the execution of sentences in Brazil, whose doctrinal debate has not gone beyond

1 Doutorando e mestre em Direito pela Universidade de São Paulo. Defensor Público da Defensoria Pública do Estado de São Paulo. 
the legal nature of this field of law. In addition to the debate on the need for judicial control of criminal execution in Brazil, it is intended to point to the complexity of the issue from concrete problems that are not very much addressed by the authors of the area. Thus, the analysis of judicial control of the progressive system, the disciplinary question, as well as the rights related to the material conditions of imprisonment, reveals serious problems that the theme engenders, especially as regards the forms of management and control of prisoners, in order to contribute with the debate to a field of law that needs to be deepened scientific.

KEYWORDs: judicial control; penal execution; progressive system; disciplinary power; conditions of imprisonment.

SUMÁRIO: Introdução; 1. Controle judicial e sistema progressivo de cumprimento de pena; 2. O controle judicial sobre o poder disciplinar penitenciário; 3. O controle judicial das condições materiais de aprisionamento; Considerações Finais; Referências.

\section{INTRODUÇÃO}

Em seu estudo sobre a comparação dos estabelecimentos prisionais e suas dinâmicas na América do Norte e na América do Sul, o criminólogo britânico Christopher Birkbeck utiliza como um dos referenciais comparativos o nível de controle judicial sobre a vida prisional $^{2}$. A maior ou menor participação do Poder Judiciário nas questões penitenciárias é um aspecto determinante das características dos sistemas prisionais pelo mundo.

No referido estudo comparativo levado a efeito especialmente entre Estados Unidos e Venezuela, Birkbeck diferencia as duas modalidades de intervenção penal no plano qualitativo, de modo a conferir às prisões do norte um efetivo caráter de encarceramento, enquanto as prisões do sul conferem um caráter que melhor se caracterizaria como internação ${ }^{3}$.

2 BIRKBECK, Christopher. Prisiones e internados: una comparación de los establecimientos penales en América del Norte y América Latina. Caderno CRH, Salvador, v. 23, n. 58, 2010, p. 138 e ss.

3 BIRKBECK, Christopher. Prisiones e internados... p. 143. 
Para o criminólogo britânico, nos modelos de "internamento", a maior intervenção judicial no curso da execução penal é um dos aspectos mais característicos. Com efeito, no Brasil, ainda que possa ser exigida alguma participação técnica e administrativa, a concessão de direitos relativos ao sistema progressivo depende de obrigatória intervenção judicial.

Nos Estados Unidos, por outro lado, não há propriamente um sistema progressivo de execução penal, e mecanismos de saída antecipada são bastante restritos e costumam ter incidência apenas nos últimos meses de cumprimento da pena. Além disso, a decisão acerca da possibilidade de uma saída antecipada da prisão é de ordem administrativa, baseada em pareceres técnicos e sistemas de cálculo altamente objetivados.

Birkbeck atribui ao aumento do controle judicial sobre as prisões nos Estados Unidos uma parcial melhora nas condições de vida dos presos a partir dos anos $1960^{4}$, atenuando-se o princípio da "less eligibility", segundo o qual os presos devem viver em condições materiais inferiores aos dos estratos mais pobres da sociedade. Ao mesmo passo em que se edificava uma política criminal mais punitiva, inauguravam-se nos Estados Unidos iniciativas de resistência aos maus tratos da população prisional por meio da reivindicação judicial de direitos com nítido viés humanitário.

Por sua vez, aponta Birkbeck, a América Latina não vivenciou um processo de mão dupla, senão apenas seguiu com políticas criminais repressoras e com o aumento do encarceramento a partir dos anos 1980, sem que se verificasse um contramovimento de resistência às condições de vida nas prisões ${ }^{5}$.

No Brasil, a questão ganha relevo a partir de 1984 com a promulgação da Lei de Execução Penal, muito embora tradicionalmente a execução penal tenha sido um dos campos do direito com o mais baixo nível de pesquisa, tanto quantitativa quanto qualitativamente. No plano doutrinário, o debate sobre a natureza da execução penal, se jurisdicional ou administrativa, possui larga tradição, prevalecendo a posição segundo

4 BIRKBECK, Christopher. Prisiones e internados... p. 138.

5 Anote-se, no entanto, que o autor não contextualiza o momento histórico da América Latina, cuja conjuntura era de controle do Estado por ditaduras militares ou civis-militares. 
a qual "só a visão jurisdicional da execução penal é idônea a elevar o processo a estatura e nível constitucional" ${ }^{\text {. }}$

Com efeito, o sistema progressivo de cumprimento de pena adotado no Brasil exige a manifestação judicial em cada etapa da execução penal, o que não significa necessariamente que a execução penal brasileira possa ser classificada propriamente como jurisdicionalizada.

Ademais, a execução penal não abarca somente os pedidos individuais relacionados à progressão da pena em sentido amplo, mas também os direitos individuais e coletivos relacionados às condições materiais de aprisionamento, tais como a saúde, educação, trabalho e salubridade da população prisional, por exemplo.

Pretende-se no presente trabalho realizar uma abordagem inicial sobre aspectos do controle judicial da execução penal no Brasil e suas principais contradições e ambiguidades. Para tanto, a jurisdicionalização da execução penal será examinada tanto em relação à progressão da pena em sentido amplo, que chamaremos de plano individual, quanto na esfera das condições materiais de aprisionamento, o plano coletivo.

Com o estudo de tais aspectos da jurisdicionalização da execução penal, o presente trabalho pretende explorar as contradições que superam a mera discussão acerca da natureza jurídica do processo de execução penal para adentrar na temática que resta oculta no debate tradicional: as formas de gestão e controle das pessoas presas.

\section{Controle judicial e sistema progressivo de CUMprimento DE PENA}

O advento da Lei de Execução Penal em 1984 não só trouxe uma série de direitos aos presos, como também definiu uma extensa competência do juiz da execução penal em seu art. 66. Trata-se de uma

6 GRINOVER, Ada Pellegrini; GOMES FILHO, Antonio Magalhães; FERNANDES, Antonio Scarance. A exigência de jurisdicionalização da execução penal. Fascículos de Ciências Penais. n. 3, v. 4, 1991. p. 7. Sobre o tema, cf. CASTILHO, Ela Wiecko Volkmer de. Controle da legalidade na execução penal: reflexões em torno da jurisdicionalização. Porto Alegre: Sergio Antonio Fabris Editor, 1988. 
intervenção obrigatória do juiz, ou seja, tais direitos só podem ser usufruídos por seus destinatários se houver decisão judicial ao seu respeito.

Parte dos direitos previstos na Lei de Execução Penal são diretamente relacionados à progressão da pena em sentido amplo, ou seja, às dinâmicas de transformação do cumprimento da pena com maior ou menor liberdade. São direitos subjetivos na execução penal, chamados vulgar e incorretamente de benefícios prisionais, a progressão de regime, o livramento condicional, a remição, a saída temporária, a comutação e o indulto.

Tais direitos possuem requisitos previstos na lei, geralmente um lapso temporal e um elemento disciplinar ou comportamental, cabendo ao juiz declarar a existência dos referidos requisitos. Nesta matéria, portanto, a legislação brasileira conferiu ao Poder Judiciário a competência para declarar a existência dos referidos direitos, ao contrário de diversos outros países nos quais tal tarefa fica a cargo da administração prisional.

No entanto, o mandamento legal não implica, por si só, uma garantia de regular jurisdicionalização da execução penal. Isto porque a sua principal característica é a lentidão no exercício da jurisdição, que acaba por torná-la um mecanismo muito mais violador do que garantidor dos direitos previstos em lei.

O cotidiano nas varas de execução penal no Brasil demonstra que o funcionamento da maior parte destas é verdadeiramente caótico, como apontou relatório do Conselho Nacional de Justiça. ${ }^{7}$ Para além de um funcionamento burocrático e irregular, trata-se de verdadeira violação de direitos com efeitos concretos sobre a liberdade das pessoas sob jurisdição, uma vez que os pedidos de efetivação de direitos demoram meses ou anos para serem analisados, em frontal violação tanto ao art. 196 da Lei de Execução Penal, quanto à determinação constitucional de duração razoável do processo ${ }^{8}$.

7 Cf. Mutirão carcerário: raio-x do sistema penitenciário brasileiro. Conselho Nacional de Justiça, 2012. Disponível em: <http://www.cnj.jus.br/images/ pesquisas-judiciarias/Publicacoes/mutirao_carcerario.pdf $>$. Acesso em: 17 dez. 2017.

8 CACICEDO, Patrick. A natureza declaratória da decisão de progressão de regime: notas sobre o julgamento do HC 115.254 no Supremo Tribunal Federal. Revista Brasileira de Ciências Criminais, v. 124, 2016, p. 360. 
Como consequência, os períodos de cumprimento de pena previstos em lei para os direitos da execução penal não são observados e as pessoas acabam por cumprir a pena de maneira significativamente mais gravosa do que o previamente determinado pelo legislador penal ${ }^{9}$. No plano concreto da execução penal, o que ocorre de fato é a alteração dos prazos definidos em lei pelo juiz, que se perfaz pela demora na análise dos direitos no curso da execução da pena. Não se trata de mera falha burocrática, mas verdadeira violação de direitos com efetiva alteração dos prazos previstos em lei.

A progressão de regime, por exemplo, é concedida muito após um sexto do cumprimento da pena no caso de crimes não hediondos, sendo mais frequente até mesmo que ocorra após um terço, marco do livramento condicional para condenados primários, do que no marco legalmente garantido.

No caso de penas curtas, a lentidão das varas de execução penal acaba por revigorar, na prática, o inconstitucional cumprimento de pena em regime integralmente fechado, pois a pena se esgota antes que o juiz consiga analisar qualquer dos direitos da execução penal ${ }^{10}$. Situação semelhante ocorre com a remição de pena, sendo comum que muitos dias de trabalho ou estudo durante a execução da pena não sejam descontados até o seu término.

Com relação ao indulto e à comutação, a notoriedade do burocrático funcionamento das varas de execução penal motivou, igualmente, previsões específicas nos Decretos Presidenciais de indulto para sua aplicação mais célere, prevendo tanto a prioridade a esse direito que implica em imediata liberdade, quanto o incentivo a organização de mutirões específicos para sua efetivação (art. 11, § 3. ${ }^{\circ}$ e $4 .^{\circ}$ do Dec. 8.615/2015). Com efeito, na data da publicação do decreto a pena é declarada extinta, faltando apenas a declaração judicial nesse sentido. A lentidão na análise do indulto, por exemplo, faz com que milhares de pessoas cumpram por meses ou anos penas que juridicamente estão extintas.

Outro reconhecimento da morosidade das varas de execução penal e do consequente prejuízo à liberdade dos jurisdicionados na execução

9 Cf. Mutirão carcerário...passim.

10 CACICEDO, Patrick. A natureza declaratória da decisão de progressão de regime..., p. 360. 
penal encontra-se na edição, em 2012, da Lei Federal 12.714, que pretendeu criar um sistema de acompanhamento da execução das penas, com ferramentas que informem as datas estipuladas para os direitos por meio de avisos eletrônicos que possibilitariam a concessão dos direitos na data prevista em lei, quando presentes os requisitos legais.

A despeito da previsão legal e da intensa informatização que os processos judiciais têm sofrido no Brasil de maneira geral, o sistema informatizado da execução penal ainda inexiste no plano nacional. A lentidão da vara de execução penal do Rio de Janeiro, por exemplo, motivou a Defensoria Pública local a impetrar mais de cinco mil habeas corpus em dezembro de 2015 , todos motivados pela lentidão na análise dos pedidos com consequências reais para o direito de liberdade de seus defendidos. ${ }^{11}$

Como se não bastasse a habitual e notória morosidade das varas de execução penal no Brasil, é uma prática comum, com expressiva aceitação dos tribunais ${ }^{12}$, a exigência de um exame criminológico para referendar a decisão judicial sobre progressão de regime. Tal exame, desprovido de qualquer nível de cientificidade ${ }^{13}$, realiza um julgamento, muitas vezes moral, sobre a personalidade da pessoa presa, a fim de apontar se está ou não em condições de progredir para regime mais benéfico.

Trata-se de uma prática que retira o próprio caráter jurisdicional da atividade judicial, como defende Luigi Ferrajoli, que aponta como "misterioso" o juízo feito sobre a personalidade dos presos, sem que se possa qualifica-lo como jurisdicional, pois sua substância permanece administrativa. ${ }^{14}$

11 Disponível em: <www.conjur.com.br/2015-dez-11/defensoria-rj-impetramil-hcs-vara-execucoes-penais>. Acesso em: 23 nov. 2016.

12 Como são exemplos a súmula $n^{\circ} 439$ do Superior Tribunal de Justiça e a súmula vinculante $\mathrm{n}^{\circ} 26$ do Supremo Tribunal Federal.

13 Cf. CARVAlHO, Salo de. O (Novo) Papel dos “Criminólogos” na Execução Penal: as alterações estabelecidas pela Lei 10.792/03. In: CARVALHO, Salo de (Org.). Crítica à Execução Penal. $3^{\circ}$ ed. Rio de Janeiro: Lumen Juris, 2007.

14 "O poder conferido aos órgãos da execução penal é, pelo contrário, um poder altamente potestativo, ancorado não na comprovação pública de fatos claramente predeterminados pelas leis e pelos requisitos relativos à taxatividade, materialidade, ofensividade e culpabilidade, senão nas valorações da personalidade do preso: um poder, então, substancialmente misterioso que funciona à sombra ('arcano potere che agisce nell'ombra'). A circunstância 
Assim, seja porque na realidade concreta viola os direitos ao invés de implementá-los, seja porque realiza valorações sobre a personalidade do condenado, a atividade judicial não pode ser tão facilmente considerada jurisdicional propriamente dita.

O reflexo da morosidade nos pleitos judiciais que determinam o destino das pessoas presas é sentido dentro do ambiente prisional com grande aflição. Em pesquisa de campo, Rafael Godoi relata em diversas passagens a preocupação dos presos com o andamento do processo de execução penal e seus pedidos. Ao descrever a dinâmica de uma visita como agente da Pastoral Carcerária, Godoi relata que após a oração, os primeiros questionamentos dos presos referem-se justamente ao andamento dos pedidos na vara de execução penal. ${ }^{15}$

Godoi aponta que a relação do preso com a indefinição do processo de execução encerra uma dimensão estruturante da experiência da punição no estado de São Paulo ${ }^{16}$. Por outro lado, as contradições da jurisdicionalização da execução penal com a dinâmica burocrática do funcionamento do sistema progressivo também não passaram ao largo da análise de Rafael Godoi, que confere à demora na concessão dos direitos

seguramente positiva de que este poder seja hoje exercido por uma Magistratura de Vigilância, em alguns casos, por Magistrados com altos valores - e não por, como nos tempos de Carrara, aqueles a quem chamava 'sinedrio de esbirros' - não lhe muda a substância administrativa.” (FERRAJOLI, Luigi. Jurisdicción y ejecución penal. La cárcel: uma contradicción institucional. Revista Critica y Poder, Barcelona, n. 11, 2016, p. 3-4) (tradução livre).

15 "Eu e Fátima ficamos de pé, perto da mesa, cada um rodeado por presos ansiosos em conversar e tirar dúvidas. Além das questões pontuais sobre as informações necessárias para a realização do pedido do extrato, todo um universo de questões processuais nos é apresentado. O diálogo se inicia com um aperto de mãos, o preso então explica sua situação. Muitos têm uma condenação de $\mathrm{X}$ anos, já cumpriram $\mathrm{Y}$ da pena, tendo, portanto, lapso para progredirem de regime ou mesmo para serem soltos, no entanto, estão lá ainda, sem informação sobre o andamento de seus benefícios. Outros: ou têm um advogado particular que deixou de atuar em seu caso; ou já progrediram para o regime semiaberto e ainda não foram transferidos; ou apelaram da condenação e não têm informação alguma sobre esse processo; ou acabam de ser condenados num outro processo e não sabem como vai ficar a pena." (GODOI, Rafael. Fluxos em cadeia: as prisões em São Paulo na vidada dos tempos. Tese (Doutorado em Sociologia) - Departamento de Sociologia, FFLCH, Universidade de São Paulo, São Paulo, 2015. p. 81).

GODOI, Rafael. Fluxos em cadeia... p. 82. 
na execução penal um papel prático real de imperativo securitário da contenção incapacitante da população prisional no contexto de abandono dos ideais ressocializadores da prisão contemporânea. ${ }^{17}$

Observa-se, portanto, que até mesmo em atividades cuja intervenção judicial é obrigatória por lei, como no caso dos direitos relacionados ao sistema progressivo de cumprimento da pena, não se pode assegurar que a jurisdição exerça o seu papel declarado de garantia dos direitos. Pelo contrário, nesta seara, a intervenção judicial parece exercer uma função oposta ao que dela se espera, posto que na realidade concreta a atividade judicial tem sido muito mais um mecanismo de violação do que de garantia de direitos na execução penal.

A defesa da jurisdicionalização da execução penal nesta seara oculta o concreto prejuízo à liberdade humana exercido pelo funcionamento do próprio controle judicial sobre as penas. O atraso na efetivação de direitos do sistema progressivo configura constrangimento ilegal ao jurisdicionado, que, para além dos mecanismos existentes na legislação processual brasileira, deveria ser objeto de efetiva reforma no sentido de realmente afastar o controle judicial burocrático para o fim de efetivar os direitos em tela, que deveriam ser automaticamente concedidos quando preenchidos os requisitos legais, restando a atividade judicial necessária apenas nos casos em que o órgão do Ministério Público demonstrasse por iniciativa própria que determinados direito não se encontra presente concretamente.

Trata-se, aqui, de verdadeira mudança de paradigma, a partir do qual se defende uma radical inversão na forma de concessão dos direitos do sistema progressivo da execução penal, no qual cumpriria à acusação a comprovação da ausência dos requisitos legais de cada direito, sendo devida a intervenção judicial somente nesses casos. Desta forma,

17 "Se, nesse sistema de justiça, os prazos procedimentais são sistematicamente extrapolados, se as intervenções dos diversos agentes são por demais protocolares e se a desorganização logística é a marca da relação entre as diferentes agências, o particular regime de processamento que viabiliza o funcionamento do sistema penitenciário não deve ser apenas visto como obviamente incompatível com o código legal, mas, sobretudo, como a compatibilização prática, empírica, entre o imperativo securitário da contenção incapacitante e as exigências legais de um sistema que se caracteriza pela progressividade das penas e pela jurisdicionalização da execução" (GODOI, Rafael. Fluxos em cadeia..., p. 92-93). 
enquanto não houver manifestação judicial negando o referido direito, tem-se como automática sua efetivação assim que cumpridos os lapsos temporais previstos em lei, sem necessidade de intervenção judicial. Para tanto, por evidente, é necessária reforma legal regulamentando de maneira clara a questão.

O debate sobre a jurisdicionalização da execução penal, portanto, deve levar em conta a realidade concreta do cumprimento de pena no Brasil e o fato de que o atual regime de controle judicial da pena no sistema progressivo funciona muito mais como um mecanismo violador do que garantidor dos direitos dos jurisdicionados.

\section{O CONTROLE JUDICIAL SOBRE O PODER DISCIPLINAR PENITENCIÁRIO}

Talvez o ponto mais crítico da carência de controle judicial sobre a execução penal no Brasil resida na questão disciplinar. Definida legalmente como a colaboração com a ordem, a obediência às determinações das autoridades e seus agentes e o desempenho do trabalho (art. 44 da Lei de Execução Penal), a disciplina na execução da pena tem um papel central e determinante na forma de cumprimento da pena.

Assim, o comportamento positivo do preso figura como requisito para que possa usufruir de tais direitos e ter progressividade em sua pena. A comprovação do bom comportamento prisional fica, em regra, à cargo do diretor do estabelecimento prisional, autoridade administrativa que possui amplo poder sobre a liberdade do preso durante o cumprimento da pena.

Por outro lado, o comportamento do preso não só pode impedir que usufrua de direitos previstos em lei, como pode piorar significativamente o cumprimento da pena, pois uma das consequências legais da prática de uma falta grave é a possibilidade de regressão de regime, ou seja, o mau comportamento não só impede o acesso a um regime de maior liberdade, como determina uma piora concreta na forma de cumprimento da pena.

Com efeito, é por meio da imposição de faltas disciplinares, notadamente as de natureza grave, que os efeitos do controle disciplinar interferem na liberdade da pessoa que cumpre pena. As faltas disciplinares de natureza grave estão previstas no art. 50 da Lei de Execução Penal para as penas privativas de liberdade e têm como característica principal o caráter aberto de suas descrições. 
A descrição vaga das faltas dá margem a grande arbítrio por quem tem o dever legal de subsumir as condutas na descrição do art. 50, da Lei de Execução Penal. ${ }^{18}$ Imagine-se, por exemplo, a quantidade de condutas que podem ser enquadradas em desobediência ao servidor ou desrespeitar qualquer pessoa com quem deva se relacionar, que são hipóteses previstas na primeira parte do inciso VI, do art. 50 acima referido.

A única falta grave com descrição taxativa, a do inciso VII, no entanto, foi desfigurada pela equivocada interpretação que recebeu dos tribunais superiores, que permitem até mesmo que a apreensão de um chip possa configurar falta grave ${ }^{19}$, quando sua descrição legal é clara no sentido de exigir aparelho com capacidade de comunicação.

Ocorre que a Lei de Execução Penal conferiu a tarefa de apurar a prática de falta grave à autoridade prisional, por meio de procedimento administrativo interno. Assim, a falta que ocorre dentro da unidade prisional é apurada por seus próprios funcionários, que têm o poder de definir o destino do preso. Por exemplo, se um agente penitenciário diz ter sido desrespeitado por um preso, são as próprias autoridades administrativas que decidirão se houve ou não falta grave, após oitiva do acusado e garantido o direito de defesa na sindicância.

A natureza administrativa da falta conferiu competência igualmente administrativa para sua apuração. Contudo, a despeito da classificação legal e da aceitação doutrinária e jurisprudencial da natureza administrativa da falta grave, tal posicionamento não pode prosperar diante de um confronto com a realidade concreta dos efeitos que a falta disciplinar produz sobre a liberdade da pessoa condenada criminalmente.

O ponto central da crítica à administrativização das faltas disciplinares é que seus efeitos concretos são mais gravosos para a liberdade do que grande parte dos crimes previstos na legislação penal. Por isso, a natureza jurídica das faltas disciplinares precisa de urgente reflexão crítica, pois seus efeitos superam os trinta dias de isolamento, suspensão ou restrição de direitos, previstos no art. 58 da Lei de Execução Penal.

18 Nesse sentido, cf. ROIG, Rodrigo Duque Estrada. Direito e prática histórica da execução penal no Brasil. Rio de Janeiro: Revan, 2005, p. 143.

19 Cf. STF, RHC 117.985-DF, Rel. Min. Rosa Weber; STJ, HC 278.584-SP, Rel. Min. Maria Thereza de Assis Moura. 
Grande parte dos crimes previstos na legislação brasileira permite a aplicação de institutos despenalizadores ou desencarcerizadores como a transação penal, a suspensão condicional do processo ou da pena e a substituição da pena privativa de liberdade por pena restritiva de direitos, por exemplo. Isso significa que, a depender de circunstâncias pessoais, como a reincidência, a maior parte dos crimes permite que seu autor não cumpra pena em estabelecimento prisional.

À título de exemplo, se uma pessoa pratica o crime de injúria, ofendendo a dignidade ou o decoro de outrem, só será processada se a vítima representar criminalmente e apresentar queixa-crime no prazo de seis meses. Ainda que seja processada, poderá, por exemplo, ser feita uma transação penal, sem que conste qualquer registro criminal contra o réu. Por sua vez, se uma pessoa presa desrespeita um agente penitenciário no curso da execução da pena, conduta muito mais leve do que o crime de injúria, pode ter contra si uma sanção maior do que a maioria dos crimes.

Com efeito, uma pessoa que cumpre pena de trinta anos por diversos roubos, e trabalhou e estudou durante toda sua pena, progride de regime após cinco anos. Depois de cumprir mais um sexto do restante da pena (pouco mais de quatro anos), quando completou os requisitos para progredir ao regime aberto, tem contra si atribuída uma falta de desrespeito a um funcionário. Se tal falta não fosse a ele atribuída, poderia cumprir o restante da pena (mais de vinte anos) em regime aberto, com ampla margem de liberdade, posto que não seria cumprida em estabelecimento prisional ${ }^{20}$. Todavia, se condenado pela falta grave, teria como consequência a regressão ao regime fechado, ficando, pelo menos mais dez anos preso, pois teria que cumprir novamente um sexto de pena em regime fechado e outro sexto de pena em regime semiaberto para somente então pleitear a progressão ao regime aberto novamente. Além disso, o sentenciado perderia até um terço dos dias remidos por trabalho e estudo.

20 Conforme dados do Levantamento Nacional de Informações Penitenciárias - INFOPEN, apenas 1\% da população prisional brasileira cumpre pena em estabelecimento prisional destinado ao regime aberto, sendo que dezesseis estados da federação sequer registram a existência de referido estabelecimento. Disponível em: <http://www.justica.gov.br/seus-direitos/politica-penal/documentos/infopen_dez14.pdf >. Acesso em: 14 out. 2017. 
No exemplo acima citado, uma singela conduta de desrespeitar funcionário poderia ensejar mais de dez anos de encarceramento, tempo muito superior, por exemplo, à pena mínima do crime de homicídio, que é de seis anos de reclusão. O exemplo mencionado, corriqueiro no interior das unidades prisionais, demonstra que não se pode aceitar a natureza administrativa das faltas disciplinares. Sua natureza é penal, tendo em vista que enseja efetiva restrição de liberdade do sujeito, de tal modo que demanda a submissão a processo com as mesmas garantias de um processo penal efetivamente jurisdicional.

A exigência de mera sindicância para caracterização de falta disciplinar, submete os presos a intenso e arbitrário controle da direção prisional, que pode simplesmente enquadrar qualquer conduta irregular das pessoas presas nas vagas e abertas hipóteses de falta do art. 50 da Lei de Execução Penal, naquilo que Michel Foucault chama de soberania punitiva $^{21}$ da administração penitenciária.

Assim como a indefinição do processo de execução referida no tópico precedente, Rafael Godoi também atribui às sanções disciplinares ("castigo") uma dimensão estruturante do cumprimento de pena em São Paulo na medida em que interfere, intensamente, nas condições materiais e temporais de cumprimento de pena. ${ }^{22}$

A natureza administrativa das faltas disciplinares não passa de uma atribuição nominal ou classificatória, que resta desconstruída a partir de seus efeitos na realidade concreta. Se a falta disciplinar pode gerar, e frequentemente gera, efeitos mais graves do que a maioria dos crimes, não se pode admitir outra natureza a elas que a de verdadeira sanção penal, que enquanto tal demandam a instauração do devido processo legal com todas as garantias de uma pessoa regularmente acusada de um crime.

A natureza penal das faltas e sanções disciplinares demanda, portanto, a aplicação de todas as garantias penais e processuais penais da mesma forma como ocorre na acusação de toda e qualquer infração penal. No plano processual em especial, exige-se no campo disciplinar da execução penal uma aplicação integral do devido processo legal com plena jurisdicionalização do procedimento de apuração de faltas disciplinares.

21 FOUCAULT, Michel. Vigiar e Punir: história da violência nas prisões. Petrópolis: Vozes, 1999, p. 207.

22 GODOI, Rafael. Fluxos em cadeia...p. 97. 
No Brasil, no entanto, a jurisdicionalização não encontra amparo na realidade da execução penal. Em alguns estados da federação exige-se uma mera homologação judicial com manifestação da defesa e da acusação, mas sem qualquer garantia processual ou mesmo a possibilidade de oitiva do acusado ou testemunhas, muito menos a produção de provas. Em outros estados não há qualquer manifestação judicial acerca da falta. A situação brasileira com relação à apuração de falta disciplinar varia de um procedimento administrativo ou de mera homologação judicial, o que não pode ser considerado jurisdicional pois não há um devido processo legal para tanto.

Não resta dúvida de que, por conta dos efeitos práticos da apuração disciplinar, é aqui o maior déficit de controle judicial na execução penal, o que confere grande arbítrio à administração penitenciária no destino da execução penal da população carcerária brasileira.

\section{O CONTROLE JUDICIAL DAS CONDIÇÕES MATERIAIS DE APRISIONAMENTO}

A outra categoria de direitos da execução penal é aquele referente às condições do encarceramento, ou direitos coletivos, como educação, saúde, higiene e demais direitos relacionados à vida da população prisional. Esta categoria de direitos raramente é objeto de debate quando se trabalha a questão da jurisdicionalização da execução penal, normalmente atrelada aos direitos ligados ao sistema progressivo e à questão da apuração de falta disciplinar.

Neste caso, a natureza da atividade judicial é ainda mais confusa. A Lei de Execução Penal trouxe a seguinte competência ao juiz da execução penal nessa seara:

Art. 66. Compete ao Juiz da execução:

VI - zelar pelo correto cumprimento da pena e da medida de segurança;

VII - inspecionar, mensalmente, os estabelecimentos penais, tomando providências para o adequado funcionamento e promovendo, quando for o caso, a apuração de responsabilidade;

VIII - interditar, no todo ou em parte, estabelecimento penal que estiver funcionando em condições inadequadas ou com infringência aos dispositivos desta Lei; 
É notório que as prisões no Brasil constituem um ambiente de irregularidades e violações de direitos de toda ordem. As penas não são cumpridas corretamente e os estabelecimentos estão em condições aviltantes e com infringência de todos os dispositivos legais relacionados, para usar os termos dos citados incisos do art. 66 da Lei de Execução Penal.

Ora, se compete ao juiz zelar pelo correto cumprimento da pena, tomar providências para o adequado funcionamento dos estabelecimentos prisionais e interditar aquele que estiver em condições inadequadas ou com infringência aos dispositivos da Lei de Execução Penal, o confronto com a realidade prisional brasileira aponta de imediato que há problemas graves com essa competência judicial.

Com efeito, não se tem notícia no Brasil de interdições de estabelecimentos prisionais por condições inadequadas de funcionamento. As notícias frequentes, porém, são da barbárie que representa o sistema penitenciário brasileiro e a violação de toda sorte de direitos.

No campo jurídico construiu-se a ideia de que a competência judicial conferida pelos dispositivos legais citados não é propriamente jurisdicional, mas uma competência administrativa exercida pelo juiz da execução penal. Trata-se, portanto, de uma peculiar construção jurídica que retira o caráter jurisdicional conferido pela Lei de Execução Penal e a transforma em atividade administrativa.

Desta forma, o ato do juiz, agora administrativo, não possui os efeitos de uma decisão judicial, que é tida como ordem e tem graves consequências em caso de descumprimento. Por tal construção jurídica, apenas compete ao juiz recomendar a regularização daquilo que não estiver em conformidade com as normas, sob pena de interdição do estabelecimento no todo ou em parte.

Tal entendimento foi consolidado pelo Conselho Nacional de Justiça ao ser consultado formalmente sobre o assunto:

Como se pode observar, além das atribuições jurisdicionais, a LEP prevê hipóteses de competência do juiz da execução para o desempenho de atividades administrativas, dentre as quais a realização de inspeções em estabelecimentos prisionais e a adoção de medidas voltadas ao adequado funcionamento do sistema carcerário. ${ }^{23}$

${ }^{23}$ Conselho Nacional de Justiça, Consulta n ${ }^{\circ}$. 0000002-38.2016.2.00.0000. 
Com isso, alguns estados da federação criaram a figura do juiz-corregedor de presídios, inspirada na figura do juiz de vigilância do direito espanhol ${ }^{24}$, mas com as devidas "adaptações" ao caso brasileiro.

Para além de uma mera inefetividade decorrente da administrativização de uma atividade legalmente conferida ao juiz, esta interpretação legal tem o efeito concreto de impedir o acesso à justiça de todas as formas. Isso porque a tentativa de jurisdicionalização por meio de provocação ao juiz da execução penal é rejeitada ou recebida como demanda administrativa.

Por outro lado, se outro juiz é provocado, por exemplo, o da Fazenda Pública (juiz competente em ações em que o Estado é réu), este se julga incompetente porque a própria Lei de Execução Penal atribui claramente a competência ao juiz da execução penal. Assim, o comando constitucional de inafastabilidade da jurisdição ${ }^{25}$ acaba sendo excepcionado por esta construção jurídica que confere ao juiz da execução penal uma competência administrativa nessa espécie de matéria.

Como consequência, a única categoria de pessoas que não pode pleitear jurisdicionalmente por determinados direitos é a população prisional, confirmando nos tribunais a situação de cidadãos de segunda categoria que a realidade nunca deixou esconder. Como se não bastasse o desrespeito à Constituição da República pelas condições materiais de aprisionamento aviltantes, o direito fundamental de acesso à justiça acaba por ser excepcionado na prática por uma interpretação judicial que lhe retira sua própria função jurisdicional.

Referida construção jurídica vislumbra retirar do Poder Judiciário sua responsabilidade com relação à barbárie que representa a realidade prisional brasileira, porém representa ao mesmo tempo umas das próprias razões de manutenção dela. A jurisdicionalização da execução penal aqui é mais uma vez negada pelo próprio Poder Judiciário, o que acaba por representar uma forma de manutenção das coisas como estão, uma forma de

${ }^{24}$ Cf. RIVERA BEIRAS. Iñaki. La cuestión carcelaria: historia, epistemologia, derecho y politica penitenciaria II. Buenos Aires: Editorial del Puerto, 2009, p. 359 e ss.

25 "Art. 5 XXXV. A lei não excluirá da apreciação do Poder Judiciário lesão ou ameaça a direito." 
legitimação das mazelas do sistema penitenciário brasileiro, ao contrário do movimento ocorrido nos Estados Unidos a partir dos anos 1960, cujo aumento do controle judicial sobre as prisões conferiu uma parcial melhora nas condições de vida dos presos, segundo relato de Christopher Birkbeck ${ }^{26}$.

\section{Considerações finais}

A questão do controle judicial sobre a vida prisional assume no Brasil características peculiares. A despeito de pouco estudado, o tema traz importantes consequências no cotidiano carcerário, além de ser fundamental na compreensão e conhecimento da situação prisional no Brasil.

O tema pode ser estudado a partir de três formas de controle judicial das penas. A mais tradicional e legalmente obrigatória é a atividade judicial exercida no sistema progressivo de cumprimento de pena, que tem como característica principal a morosidade na análise dos pleitos jurídicos. A forma como tal atividade judicial é exercida tem como efeito concreto muito mais uma violação dos direitos do que a sua garantia, que é a função oficialmente conferida ao Poder Judiciário.

A outra forma de analisar o grau de jurisdicionalização da execução penal é pelo papel exercido pelo juiz no controle disciplinar dos presos. Nesse aspecto, o sistema brasileiro é notadamente perverso, pois deixa o controle disciplinar da população prisional ao arbítrio da autoridade administrativa penitenciária. O controle da vida dos presos por meio da disciplina prisional tem o poder de decidir o destino da execução penal de cada um, cuja punição disciplinar pode significar uma medida pior do que os mais graves crimes previstos na legislação. A ausência de jurisdicionalização nesta seara permite o arbítrio e potencializa o poder dos agentes penitenciários em detrimento da liberdade dos presos.

Por fim, a questão dos direitos relacionados às condições materiais de aprisionamento apresenta uma peculiar atuação judicial, pois o próprio Poder Judiciário nega sua atividade como jurisdicional. A consequência dessa negativa de jurisdição é uma vedação do acesso à justiça por parte da população prisional, criando-se a única exceção à garantia constitucional da inafastabilidade da jurisdição, além da manutenção do quadro de verdadeira barbárie representada pelas abjetas condições materiais de aprisionamento no Brasil.

26 BIRKBECK, Christopher. Prisiones e internados... p. 138. 
Assim, o controle judicial da execução penal no Brasil é caracterizado ora pela ausência, ora por uma presença prejudicial da atividade judicial, cujo resultado é o prejuízo à dignidade e à liberdade da população prisional. Trata-se de uma contradição perversa que supera o debate teórico sobre a natureza jurídica da execução penal e remete a discussão sobre a jurisdicionalização da execução para o plano das dinâmicas de controle social punitivo na era do grande encarceramento.

As três formas de controle judicial sobre a execução penal analisadas no presente estudo permitem, portanto, deslocar o debate sobre a jurisdicionalização da execução penal para as formas de gestão e controle das pessoas presas. O deslocamento do debate sobre a natureza jurídica da execução penal para as manifestações concretas do controle judicial do cumprimento de pena no Brasil possibilita superar o caráter meramente jurídico e idealista da questão, elevando-a para a materialidade das relações de poder na prisão contemporânea.

\section{REFERÊNCIAS}

BIRKBECK, Christopher. Prisiones e internados: una comparación de los establecimientos penales en América del Norte y América Latina. Caderno CRH, Salvador, v. 23, n. 58, 2010. https://doi.org/10.1590/s0103-49792010000100009 CACICEDO, Patrick. A natureza declaratória da decisão de progressão de regime: notas sobre o julgamento do HC 115.254 no Supremo Tribunal Federal. Revista Brasileira de Ciências Criminais, São Paulo, v. 124, 2016.

CARVAlHO, Salo de. O (Novo) Papel dos "Criminólogos" na Execução Penal: As Alterações Estabelecidas pela Lei 10.792/03. In: CARVALHO, Salo de (Org.). Crítica à Execução Penal. $3^{\circ}$ ed. Rio de Janeiro: Lumen Juris, 2007.

CARVALHO, Salo de. Pena e Garantias. 3. ed. Rio de Janeiro: Lumen Juris, 2008. CASTILHO, Ela Wiecko Volkmer de. Controle da legalidade na execução penal: reflexões em torno da jurisdicionalização. Porto Alegre: Sergio Antonio Fabris Editor, 1988.

CINTRA JÚNIOR, Dyrceu Aguiar Dias. A jurisdicionalização do processo de execução penal : o contraditório e a ampla defesa. Revista Brasileira de Ciências Criminais, n. 9, v. 3, 1995.

CONSELHO NACIONAL DE JUSTIÇA. Mutirão carcerário: raio-x do sistema penitenciário brasileiro. Conselho Nacional de Justiça, 2012. Disponível em: <http:// 
www.cnj.jus.br/images/pesquisas-judiciarias/Publicacoes/mutirao_carcerario. pdf>. Acesso em: 17 dez. 2017.

FERRAJOLI, Luigi. Jurisdicción y ejecución penal. La cárcel: uma contradicción institucional. Revista Critica y Poder, Barcelona, n. 11, 2016.

FOUCAULT, Michel. Vigiar e Punir: história da violência nas prisões. Petrópolis: Vozes, 1999.

GODOI, Rafael. Fluxos em cadeia: as prisões em São Paulo na vidada dos tempos. Tese (Doutorado em Sociologia) - Departamento de Sociologia, FFLCH, Universidade de São Paulo, São Paulo, 2015. https://doi.org/10.11606/t.8.2015. tde-05082015-161338

GRINOVER, Ada Pellegrini; GOMES FILHO, Antonio Magalhães; FERNANDES, Antonio Scarance. A exigência de jurisdicionalização da execução penal. Fascículos de Ciências Penais. n. 3, v. 4, 1991

PAVARINI, Massimo; GIAMBERARDINO, André. Teoria da pena e execução penal: uma introdução crítica. Rio de Janeiro: Lumen Juris, 2011.

RIVERA BEIRAS. Iñaki. La cuestión carcelaria: historia, epistemologia, derecho y politica penitenciaria II. Buenos Aires: Editorial del Puerto, 2009.

ROIG, Rodrigo Duque Estrada. Direito e prática histórica da execução penal no Brasil. Rio de Janeiro: Revan, 2005.

\section{Informações adicionais e declarações dos autores (integridade científica)}

Declaração de conflito de interesses (conflict of interest declaration): o autor confirma que não há conflitos de interesse na realização das pesquisas expostas e na redação deste artigo.

Declaração de coautoria e especificação das contribuições (declaration of authorship): todas e somente as pessoas que atendem os requisitos de autoria deste artigo estão listadas como autores; o autor se responsabiliza integralmente por este trabalho em sua totalidade.

Declaração de ineditismo e originalidade (declaration of originality): o autor assegura que o texto aqui publicado não foi divulgado anteriormente em outro meio e que futura republicação somente se realizará com a indicação expressa da referência desta publicação original; também atesta que não há plágio de terceiros ou autoplágio. 
Dados do processo editorial (http://www.ibraspp.com.br/revista/index.php/ RBDPP/about/editorialPolicies)

- Recebido em: $18 / 10 / 2017$ Equipe editorial envolvida

- Controle preliminar e verificação de plágio: 19/10/2017

- Avaliação 1: 22/10/2017

- Editor-chefe: 1 (VGV)

- Revisores: 3

- Avaliação 2: 02/11/2017

- Avaliação 3: 05/11/2017

- Decisão editorial preliminar: 12/11/2017

- Retorno rodada de correções: 17/12/2017

- Decisão editorial final: 20/12/2017

\section{COMO CITAR ESTE ARTIGO:}

CACICEDO, Patrick. O controle judicial da execução penal no Brasil: ambiguidades e contradições de uma relação perversa. Revista Brasileira de Direito Processual Penal, Porto Alegre, vol. 4, n. 1, p. 413-432, jan./abr. 2018. https://doi.org/10.22197/rbdpp.v4i1.111

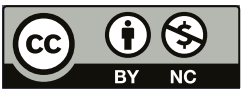

Esta obra está licenciada com uma Licença Creative Commons Atribuição-NãoComercial 4.0 Internacional. 